Is it a Few Days of Good Times and then Darkness Ensues? Long Term Performance of an Industry after Broad Reforms and Privatisation

\author{
Yaseen Ghulam ${ }^{\mathrm{a}, \mathrm{b}}$ \\ a University of Portsmouth, Portsmouth Business School, \\ Economics and Finance Subject Group \\ Richmond Building, Portland Street, PO1 3DE, UK \\ Email: yaseen.ghulam@port.ac.uk \\ Phone: +442392844127 \\ b Al Yamamah University 7010 King Fahd Road, \\ Al Qirawan, Riyadh 13541, Saudi Arabia
}




\title{
Is it a Few Days of Good Times and then Darkness Ensues? Long Term Performance of an Industry after Broad Reforms and Privatisation
}

\begin{abstract}
The long run financial performances of privatised firms have rarely been investigated. This study examines the financial and operational performance within the Pakistani cement industry utilising two decades of post-privatisation data. Broadly speaking, regression analyses confirm that long term positive impacts of reforms and privatization on profitability, output and investment are uncertain. After controlling for firm, industry and economic factors, our estimates show that privatised firms initially improved their profitability but recorded a statistically significant decline over a longer period. The sale efficiency, capacity utilisation, and leverage indicators however improved over a considerably long post ownership change period.
\end{abstract}

\section{JEL classification}

D41, L13, L61

Keywords

Financial performance; Reforms; Privatisation; Competition; Cement industry; Pakistan 


\section{Introduction}

In contrast to the stated aims of governments in the implementation of broad reforms including the privatisation programme across the world, the available empirical evidence on the actual impact of privatisation in making the overall industry and privatised firms financially viable in the long run, has either been assessed occasionally and/or conclusions are at best mixed. A number of studies from both developed and developing countries suggest instantaneous positive impact of change of ownership on firms’ financial outcomes. Some of these studies include Bishop and Kay (1989), Adam and Mistry (1992), Megginson et al. (1994), Wei et al. (2003), Boubakria et al. (2004), D’Souzaa et al. (2005), Boubakri et al. (2005), Mathur and Banchuenvijit (2007), Farinós et al. (2007), Naceur et al. (2007), Ghosh (2008), Huanga and Yao (2010), Huang and Wang (2011), and Zhang et al. (2012). There are also a number of studies particularly those related to developing and emerging countries since the beginning of century concluding that the change of policy or ownership did not produce the desired outcome, and thus firms remained miserably less capitalised, with severe issues of liquidity and profitability. The studies that concluded either no improvement in operating performance or in fact decline of the privatized firms include Harper (2001) for Czech, Boubakri and Cosset (2002) for African countries, Chen et al. (2006) and Li et al. (2007) for Chinese, and Cook and Uchida (2008) for developing countries firms.

There could be a number of reasons for these contrasting conclusions. One of the main reasons could be that a significant number of studies used only few years of post-privatisation data and concluded an improvement in performance of privatised firms, and did not consider the dynamic impact of reforms and privatisation which are likely to materialise over a longer time period. Interestingly, a significant number of early and mid-1990s studies used a relatively short time span and selected few financial ratios to evaluate the financial performance of the industry as well as privatised firms. These studies did not explicitly elaborate how newly privatised firms would adjust to changing macroeconomic environments, political risks and competition in inputs market in the long run. It takes time to make adjustments in inputs mix and to expand production capacity to realise economies of scale. Years of 
under-investment under public ownership would require a persistently longer time to increase investment spending to upgrade technology. In addition, it also takes time to adjust to a changed competitive environment for sourcing of inputs and selling of final products, and firms may adopt a 'wait and see' policy, to assess the new environment and make use of newly acquired freedom in adjusting input/output levels. Similarly, a changed competitive environment could force firms to think beyond the domestic market and start exporting surplus production as a result of significant investment in production capacity additions. The new management of privatised firms could wait for a few years to learn about the new market and competitor experience in exporting. This 'wait and see' policy, could also be the result of a labour union signing a contract with the government at the time of management transfer, to avoid political unrest due to firing workers after the transfer of ownership.

Hence, evidence of immediate positive or negative impacts on profitability and efficiency could have been due to: reductions in the labour force before privatisation of the firms, substantial increases in income from non-production sources such as bank deposits and investment income, some immediate temporary market adjustment processes in a competitive environment, pending investment decisions or aggressive investment in technology upgrades after transfers of ownership, and more importantly better macroeconomic conditions immediately after reforms and mass privatisation policies being announced. Thus, the true financial and operational benefits of reforms and privatisation could have been over or under stated by a significant number of early and mid-1990s influential empirical studies appearing in financial journals in particular.

Considering the above points, a longitudinal study of privatised firms examining a longer postprivatisation time period is more appropriate, desirable and is likely to produce robust findings. A primary objective of this study is to compare the long run financial and operational performance of privatised firms over pre- and post-policy periods. Our study covers privatised firms over a 26 year time period encompassing four business cycles, six political governments and one military government, each with its own strategy/policy. The profitability, efficiency, liquidity, solvency, output and leverage estimates derived from a longer sample period are likely to be robust to short term fluctuations in 
economic conditions and distortion created by another government policy in addition to firms' wait and see policy and the dynamic process of inputs/out market adjustments over a longer time period. We use the Pakistani cement industry as a case study which has undergone substantial adjustments as a result of deregulation and privatisation. Since the implementation of a privatisation policy in 1991-92, all of the cement producing firms in public ownership have been transferred to private owners. The producers are no longer price takers and the industry has now started exporting a large quantity of cement to neighbouring countries and the Middle East.

The contribution of this study towards existing literature is five-fold. First, rather than depending on a few selected financial ratios, we use a number of financial ratio indicators to evaluate firms' financial performance in terms of profitability, efficiency, liquidity, solvency, output and investment. This helps us in reducing the possibility of distortion created by different recordings of taxes, income and expenditures related accounting data. Second, in the context of the financial impacts of privatisation and reforms, we have not been able to identify other studies that have utilised such a long time period of data. Interestingly, Megginson (2016) summarised seventeen empirical studies produced/published since 2004 with similar objectives and indicators of post privatisation performance evaluation. Out of these, thirteen of the studies evaluated a single country's privatisation experience including eight of only Chinese, two Indian and the remaining two in the transition economies of Central and Eastern Europe. None of these studies however, covered the long period comparable to our study. Furthermore, with the exception of the Indian studies, all other countries especially China has a different economic and corporate structure compared to the majority of other developing countries. A recent study by Ghulam and Jaffry (2015) evaluated the productivity and efficiency performance of the Pakistani cement industry, but comprehensive studies of the long run financial performance of industries from non-socialist (current or previous) developing countries in particular have not been undertaken frequently. Thus, this study provides useful findings of the short, mid (up to 10 years) and long term (more than 10 years) dynamic impact of reforms and privatisation on privatised firms' operational and financial performance. 
Third, unlike a number of studies that have evaluated post-reform/privatisation financial performance, we also account for firms' heterogeneity in terms of size, location and exporting status, initial conditions, economic environment and development of industry competitive conditions in our empirical design. The endogeneity issues of a number of explanatory variables to model the determinants of financial performances are also addressed by using Hausman and Taylor's (1981) estimator. Hence, our broader conclusions are less affected by industry specific factors, changed competitive environment and prevailing economic and political conditions. Fifth, the Pakistani cement industry has been alleged to have formed a tacit collusion to earn higher profit. There have been a number of investigations by the regulatory authorities since the ‘mass privatisation’ policy in the early 1990s. The industry has been charged of setting higher prices by colluding and earning exceptional margins. The findings of this study shed some light on the validity of abnormal profit claims by consumer groups. In summary, this study provides an interesting setting to investigate how changes of ownership has affected firms' long term strategy in terms of price setting, production and cost dynamics during a period spreading over more than a quarter of a century.

The findings of this study could be summarised in five points. (1) Similar to a number of empirical studies in this area, broadly speaking, the group of privatised firms improved their profitability margins in the short run immediately after the change of ownership, but then became significantly less profitable over longer post-privatisation time periods due to less conducive economic conditions, changes in competition environment of inputs and output markets, political risks and government taxation policy. (2) The longer run impacts of reforms on privatised firms' financial efficiency, to a large extent, was positive. (3) Privatised firms improved their leverage and net-worth in the first ten years and long lasting impacts continued for the next decade. (4) The output of privatised firms approximated by inflation adjusted sales and capital investment, did not improve immediately as well over the longer run post ownership change period. (5) A parametric approach to model the determinants of firms' performance confirmed that the role of industry and firm specific factors, initial conditions before ownership changes and economic conditions was very important in determining the financial performance of privatised firms. Overall, the findings of this study cast doubts on earlier influential empirical findings concluding 
with positive impact of reforms on profitability in particular, based on few years of post-privatisation data and without due consideration to initial conditions as well as firm, industry and economy specific factors over the longer time period.

The rest of the paper is structured as follows. Section 2 contains a review of existing empirical evidence on the impact of privatisation and reforms. The cement industry’s institutional set-up and transformation are discussed in Section 3. Section 4 and 5 are dedicated for the explanation of our methodology and data sources we have used to assemble a historical financial dataset on the cement industry. We present our empirical regression results in Section 6 and provide further explanation of revered or modest longer run impact of reforms in Section 7. Finally, Section 8 contains a summary of our main findings, limitations and directions for future research.

\section{The impact of reforms and privatisation - A review of the literature}

By using comparable firms and industries that included privatised, private and state owned firms, both of the above questions have been addressed by a number of studies but are full of contrasting results (see Table 1). For simplification, we classify the literature on firms' performance analysis into two categories. The first category analyses the nature of ownership (private, state and hybrid) and the performance of the firm, while the second discusses the issue of the performance of privatised firms in the pre- and post-privatisation time periods. In the first case, broadly speaking, two sets of conclusions have emerged from empirical case studies. The first finds private ownership clearly superior, while the second favours state ownership or at least does not consider state ownership as a hurdle to the efficient operation of the firm.

In the context of the post-reform/privatisation impact on the firms' performance, two types of conclusions have emerged over the past 25 years. The initial studies by authors such as Bishop and Kay (1989), Megginson et al. (1994) and Galal et al. (1994) supported the positive impact of reforms and privatisation on operational performance of firms. Since 2000, by using a relatively longer post reforms 
sample period, more efforts have been made to compare the performance of firms in pre- and postprivatisation time periods. For a survey of such studies, we suggest readers look at Megginson (2016). This includes studies covering samples from developed, developing and emerging economies. Interestingly, similar to earlier studies, empirical evidence is inconclusive. A significant number of studies such as Villalonga (2000), Loh et al. (2003), Wei et al. (2003), Boubakri et al. (2004), D’Souzaa et al. (2005), Boubakri et al. (2005), Mathur and Banchuenvijit (2007), Farinós et al. (2007), Naceur et al. (2007), Ghosh (2008), Huang and Yao (2010), Huang and Wang (2011) and Ghulam and Jaffry (2015) concluded that firms under private management after privatisation performed better. Studies such as Harper (2001), Chen et al. (2006), Li et al. (2007) and Cook and Uchida (2008) concluded the opposite, while authors such as Boubakri and Cosset (2002) and Zhang et al. (2012) found postprivatisation performance was either mixed or showed no improvement.

[Insert Table 1 about here]

It could be argued that although there is a vast body of literature on the public-private firms' performance comparison and the impact of broader reforms and privatisation on firms' operational and financial performance, the evidence is inconclusive. A critical analysis of these studies revealed that there could have been a number of reasons for the contrasting conclusions. Firstly, it could be due to the research methodology used in each study. A significant number of studies used non-parametric method to estimate post-and pre-privatisation efficiency, productivity and financial outcome of the privatised and non-privatised firms. This method has been criticised for dealing with outliers in the data, convergence issues due to fewer numbers of observations, and being unable to account for initial conditions and joint impacts of firm and industry specific factors as well as economic environments. Parametric methods, on the other hand, are subject to criticism due to strong assumptions required to estimate production/cost/profit function parameters.

Secondly, as discussed in our introduction section, earlier pioneering and well-cited studies on the impact of reforms and privatisation on firms' financial performance in particular, published in finance 
centric journals have generally used a short time span and the aggregation of different industries. We focus on a single industry over a very long time period, with alternative proxies of firms' financial and operational performance. Our effort in compiling a large financial historical dataset from a developing country provided us with an opportunity to compute a number of alternative financial ratios for more robust and detailed analyses.

\section{Pakistani cement industry}

Reforms including privatisation policies: Similar to other countries, the Pakistani government in 1990, headed by an industrialist who was committed to a free market economy, came to power. A surging budget deficit and pressure from the donor agencies forced the government to enact 'mass privatisation' of state industrial assets. The government sold 66 manufacturing firms and commercial banks to the private sector in 1991-92.Seven cement manufacturing firms were privatised (see Table 2). The privatisation process for two more was also completed at the time but the transfer of ownership was delayed due to a payment delay, and was finalised later. The privatisation of two more firms was completed in 1996. By the middle of the 2000’s all the nationalised cement manufacturing firms had been privatised.

\section{[Insert Table 2 about here]}

Historical development of the industry: At the beginning of 1986-87, the Pakistan cement industry consisted of 17 operating plants with a total nominal installed capacity of 7.7 million tonne per year (tpy). Thirteen of the plants, comprising about 6.0 million tpy (78\% of total capacity) belonged to the state and four with installed capacity of 1.63 million tpy were in the private sector. By the end of 1996, the total number of cement manufacturing firms had increased to 23, with six new firms entering the market during 1988-96 (all in the private sector). Since that time, a number of new firms have entered the market and some older established firms were acquired by the competitor firms. The government implemented a privatisation programme within the industry, resulting in all public sector firms being privatised. A majority of existing firms expanded their production capacity subsequent to reforms and privatisation. After the 
mergers and acquisition, the number of cement manufacturing plants in the country was 21 in 2011, and the productive capacity had increased to 45 million tpy.

3.2 Industry pricing policy: In June 1985, the government of Pakistan abandoned its long-standing cement price controls and freight equalisation. Following price liberalisation, the government introduced a number of changes in its pricing procedures. The freight equalisation formula was abolished and dealers became responsible for making their own transport arrangements. The government plant managers were allowed to modify the ex-plant price. Only two plants took advantage of the more flexible pricing policy, one southern market plant selling below the government's standard ex-factory price and a northern market plant selling above it. Plant managers however, were expected to become increasingly responsive as competitive pressure from the private sector firms started to intensify. After privatisation of state-owned firms, the government lost its power over the cement sector and the 'All Pakistan Cement Manufacturer Association’ (APCMA), representing more than $80 \%$ of private and privatised firms cement manufacturers in the country, set a price upon which all its members agreed.

Market structure: The market underwent both quantitative and qualitative change after liberalisation and the privatisation process of 1991-92. The market was no longer a 'seller's market', and prices responded to market forces following events such as the commissioning of new private sector cement plants, the abandonment of cost-plus pricing, elimination of the freight subsidy and the overall competitive market environment in the aftermath of broader economic reforms, deregulation and privatisation. The home market was now divided into two main geographical zones, i.e. north and south. The former covers Khyber Pakhtunkhwa, Azad Jammu Kashmir and part of Punjab, whereas the south covers Sindh, Balochistan and the rest of the Punjab. At present, out of the total production capacity of clinker (intermediate output), about 83\% are in the north and the remaining 17\% in the south. The higher ratio of capacity located in the north is mainly due to the availability of raw material and proximity to two big export markets (India and Afghanistan). 


\section{Firms' financial performance analysis methodology - use of alternative financial ratios}

Many financial ratios have been used in empirical studies as proxies of profitability, efficiency, output, investment and leverage. It has been common to use one or two financial ratios to analyse each of the elements of the firms' financial performance. However, using a limited number of financial ratios could lead to misleading conclusions due to the different ways of reporting profit, sales, depreciation, and the cost of goods sold in addition to differences in tax treatment of income and expenditure items in different countries. Hence, rather than depending on one particular ratio we used a number of ratios for each element of the financial performance measure.

Starting with profitability, we used six alternative financial ratios. The first in this case is the widely used ratio in the earlier financial impact studies: return on sale (ROS). ROS is calculated as net after tax income/gross sale. Some other alternative financial ratios include: first return on assets $\left(\mathrm{ROA}_{1}\right)=$ net profit before tax/total assets, second return on assets $\left(\mathrm{ROA}_{2}\right)=$ gross profit (loss)/total assets, first operating profit margin $\left(\mathrm{OPM}_{1}\right)=$ (gross profit (loss)-admin \& selling expenses)/net sale (after deducting of sales tax and excise duty), second operating profit margin $\left(\mathrm{OPM}_{2}\right)=$ (gross profit (loss)admin \& selling expenses)/total assets, and gross profit margin $(\mathrm{GPM})=$ (gross profit (loss) + depreciation cost)/net sale. These alternative financial ratios are used to accommodate differences in accounting treatments of taxes, income, expenses, assets and liabilities items.

We used five ratios to evaluate firms' operating and financial efficiency. These included three commonly used workforce utilisation based ratios and two rarely used ratios such as IM and ACP: labour use efficiencies measured by net income per employee (NIE), sale per employee (SE), asset per employee (ASPE), capacity utilisation (CAPUT), interval measure (IM), and average collection period (ACP). IM is defined by adding most liquid assets including cash and short term investment and then dividing by total financial expenditures (interest and principal payments on bank loans etc.). This ratio measures the firm's strength to meet financial obligations. A higher ratio indicates that the firm's 
management is keeping a reasonable hedge against its liabilities. The ACP is defined as average receivables divided by average daily sales and is an activity or asset utilisation ratio. The ratio determines the number of days that the average receivable is pending during the year, and is closely associated with the efficiency with which assets are managed. The lower the ratio, the lower the time of collection of outstanding assets (receivables).

Similarly, two proxy ratios were computed to determine the capital investment performance: capital investment to sales (CAPSAL) and capital investment to total assets (CAPAS). We examined output by using inflation-adjusted real sales (RSALE). To measure the insurance against financial insolvency of the firms, balance sheets as well as income statement accounts were used to determine the leverage position of the firms. For liquidity, solvency and leverage, we used financial ratios such as cash ratio (CR) that utilises the most liquid current assets such as cash in hand and short-term investment in stocks divided by current liabilities, working capital ratio (WCR), net worth relative to total liabilities (NWTL), leverage ratio (LEVER), and time interest earned (TIE) ratio. Not a commonly used ratio, TIE in particularly is defined as gross profit plus depreciation minus operating expenses and then divided by financial expenses. This ratio measures the number of times resources are available to pay off financial expenses.

A number of factors could potentially affect firms' financial performance, independent of ownership change. Some authors such as Villalonga (2000), and Garia and Anson (2012) have addressed this issue by modelling profitability and other performance measures on political, economic, organisational, and firm/industry specific factors. By starting with the following general model, we followed the above mentioned studies and modelled performance $(\boldsymbol{Y})$ such as profitability, efficiency, leverage and capital expenditure represented by different financial ratios mentioned above of firm $i$ in year $t$ on firm and industry specific and macroeconomic variables as follows:

$$
Y_{i t}=\alpha+A_{1} \beta_{1}+A_{2} \beta_{2}+\mathrm{X}_{i t} \beta_{3}+\varepsilon_{i t}
$$


Where $Y_{i t}$ is the performance outcome variable of firm $i$ in period $t, \alpha$ is an intercept term, and $\beta s$ are parameters to be estimated for the firm/industry and economy related factors. $A_{1}$ represents a vector of two dummy variables that takes the value ' 1 ' for the immediate and medium or relatively long term impact of change of ownership (1-5 and 6-10 years post-change of ownership) and ' 0 ' otherwise. $A_{2}$ is a vector of two dummy variables equal to ' 1 ' for the longer time periods (11-15 and 16-20 years postchange of ownership) and ' 0 ' otherwise. In addition to these dummy variables, a series of macroeconomic and firm specific control variables are represented by the vector of variables X.

Our sample period could potentially suffer from cross-sectional dependence given the fact that the demand for cement and firms' subsequent decisions regarding marketing, technology upgrade as well as capacity additions etc. could exhibit a cyclical nature. Petersen (2009) observed that ignoring crosssectional dependence could lead to biased standards, errors and small confidence intervals. The inclusion of time period dummies could solve this issue, but this would not solve some other serious statistical issues. For example in the above model, we have not considered the role of unobserved individual firms' heterogeneity. The unobservable attributes such as the management's cumulative experience, skill set and motivations etc. could have a significant impact on firms' performance. Ignoring these in our regression model could lead the OLS estimates to suffer from an omitted variable bias.

One solution to these issues has been to use fixed or random effect panel regression models to account for unobserved individual firms' specific heterogeneity. The random effect model assumes that all unobserved variables that could have any bearing on firms' performance measures are randomly distributed across firms. Furthermore, these unobserved time invariant individual firm specific effects are uncorrelated with control variables as well as post-reform and privatisation dummy variables. The fixed effect model allows for the possibility of correlation between unobserved individual firm effects and regressors, but cannot identify time invariant variables such as geographical location of the production facility etc. The Hausman Taylor approach (Hausman and Taylor (1981)) has some clear improvements to fixed and random effect regressions as well as preserving the advantages of both fixed 
and random effect techniques. It does not require external instruments to accommodate endogeneity issues of the independent variables and hence, avoids the search for appropriate instruments and could be used to assess the impact of policy interventions on firms' financial performance measures.

The Hausman and Taylor model can be specified as follows:

$$
Y_{i t}=\alpha+\mathrm{X}_{i t} \beta_{1}+\mathrm{X}_{2 i t} \beta_{2}+\mathrm{M}_{1 i} \gamma_{1}+\mathrm{M}_{2 i} \gamma_{2}+\mu_{i}+\varepsilon_{i t}
$$

Where $\boldsymbol{Y}_{\boldsymbol{i t}}$ represents the performance indicator as discussed above for firm $i$ in $t$ time period; $\boldsymbol{\alpha}$ is the intercept term; the two vectors $\mathbf{X}$ and $\mathbf{M}$ represent sets of observed time varying and time-invariant control variables respectively that affect the firms' financial performance indicator variables. The two variables $\boldsymbol{\mu}_{\boldsymbol{i}}$ and $\boldsymbol{\varepsilon}_{\boldsymbol{i}}$ represent the individual firm fixed effects and the time varying error terms. In the above specification, the subscript ' 1 ' represents variables that are assumed to be uncorrelated with $\boldsymbol{\mu}_{\boldsymbol{i}}$ (and $\boldsymbol{\varepsilon}_{\boldsymbol{i t}}$ ), whereas the subscript '2' refers to those that are assumed to be correlated with $\boldsymbol{\mu}_{\boldsymbol{i}}$ (but still uncorrelated with $\left.\boldsymbol{\varepsilon}_{i t}\right)$.

As discussed above, we categorised the post- privatisation years into four sub-sets, 1-5 years, 6-10 years, 11-15 years, and 16-20 years since being privatised of a state-owned firm. By following the empirical literature, we used a number of variables to control for firm and industry specific variables as well as prevailing market conditions. Industry competition conditions were approximated by the Herfindahl index (based on gross sales) and average industrial profitability. The government long run taxation policy impacts were captured by the ratios of sales tax payments to total sales and excise duty payments to total sales. The role of 'learning by exporting' was approximated by the ratio of export sale to total sale. The size of the firm was measured by the firm's total production capacity. Regional differences in sourcing inputs and selling output were captured by a dummy variable equal to ' 1 ' if firms operated in the north (time-invariant control variable). Technology differences were captured by the dummy variable equal to ' 1 ' for the firms using advanced dry process technology. The accumulation 
of market knowledge was approximated by the firm's age. The product market demand conditions were approximated by the firms' capacity utilisation rate and GDP growth rates. The efficiency of a firm in using its assets to generate sale was captured by the asset turnover ratio and finally, firms' day to day cash constraints were approximated by the WCR. CAPUT and export revenues/total sale were treated as endogenous variables in our regression framework using equation (2) above.

\section{Data sources}

For the estimation of financial ratios and subsequent regression, we collected data from various sources, such as annual reports of the former Expert Advisory Cell, Government of Pakistan, annual audited accounts of the sample firms (various issues), annual un-audited accounts of the state-owned firms (various issues), annual report of the State Bank of Pakistan (various issues), Economic Survey, Ministry of Finance, Census of Manufacturing Industries (CMI), Government of Pakistan (various issues), Cement Directory (1991), National Development Finance Corporation, Government of Pakistan and Fifty Years of Pakistan Statistics.

\section{Empirical results}

In the following discussion, we present and discuss our findings from the Hausman Taylor estimator regression results of the determinants of firms' financial and operational performance measured by firms' profitability, efficiency, output, investment and liquidity and solvency indicators. As discussed in the methodology section, we treat some of the explanatory variables as endogenously determined and our empirical design and regression methodology accommodated this statistical issue. To observe the impact of reforms and privatisation over different time periods, we compare financial performance over immediate (1-5 years), mid-term (6-10 years) and longer (11-15 and 16-20 years) postprivatisation periods. In our effort to observe the combined effect of post privatisation years, we summed individual coefficients attached to each dummy variable (1-5, 6-10, 11-15 and 16-20 years after privatised). The delta method was used to calculate standard errors of summed up coefficients 
which are then subsequently used to determine significance of combined coefficients. The last four lines of tables 3-6 contains these estimates.

\section{Profitability}

In our effort to observe the net effect of change of ownership and other broader reforms after introducing controls and initial conditions such as firm and industry specific variables, and macroeconomic environment, we ran a multivariate regression on the sample of our subject group (privatised firms). Table 3 reports the regression coefficients of dummy variables for post-privatisation years among other determinants. By considering the statistically significant coefficients only, our regression results showed that three profitability ratios in particular $\mathrm{ROA}_{2}, \mathrm{OPM}_{2}$ and GPM indicated that performance improved in the first five years of the post-privatisation period. In the longer time period (16-20 years after a firm was privatised), the impact was however negative and statistically significant for three ratios including the broadly used profitability ratio ROS. The sum of coefficients also generally supported this finding and negative influence of ownership change over a longer time period (1-20 years after privatised) was also confirmed by the statistically significant coefficient for ROS in particular.

The impact of tax burdens measured by excise duty and sales tax on individual firms' profitability was negative and statistically significant for all profitability ratios. The increase in the capacity utilisation and export sale revenues was profitability enhancing and statistically significant for a significant number of profitability ratios including/excluding other income and interest expenses. As for other variables in the regression analysis, some interesting observations can be made; for instance, individual firms' performance was in line with industry trends as the coefficient for industry profitability was positive and statistically significant. The central bank interest rate had a negative and significant impact on profitability. This result is not surprising, as most of the privatised firms borrowed a significant amount of funds in the post-privatisation period to reinforce capacities, improve infrastructure and invest in marketing and distributions channels. 
The regression coefficients for other variables showed that privatised firms using the most advanced and cost efficient technology (dry) were more profitable when compared to firms using relatively less efficient methods such as the semi dry and wet, which consume more fuel and are less labour efficient. The age of the firm was also positively related with profitability indicating accumulation of knowledge and networking and distribution capacity. This further indicates that well established firms, with updated technology, were likely to be more experienced in dealing with peaks and troughs in the macroeconomic environment, demand uncertainty, and cost inflations in the longer time period. As for the privatised firms initial condition before change of ownership variables, larger sized firms at the time of privatisation maintained their superior performance in the post-privatisation period too.

[Insert table 3 about here]

\section{Efficiency}

Overall, regression results after controlling for initial conditions and factors relevant for firm/economic effects, showed that a positive impact during immediate, medium and longer term periods was statistically significant for only sale per employee (individual dummy variables coefficients showing that impact lasted over 11-15 years but sum of coefficient indicating that positive impact continued up to 20 years after change of ownership). The sum of individual coefficients related to net income per employee (NIE) also showed that the impact was positive but statistically insignificant over longer postprivatisation periods. The same could be said of assets per employee (ASPE). After privatisation, these firms used technological and production resources more efficiently, and as a result, capacity utilisation (CAPUT) improved significantly. Interestingly, individual regression coefficients for 5, 15 and 20 years post-privatisation were all positive and statistically significant.

Asset utilisation ratio in terms of average receivables and represented by an average collection period (ACP) increased over time which perhaps suggests a more lenient policy in terms of credit sales by the new management of privatised companies over a longer time period. The sum of individual coefficients did not show any statistically significant marked improvement/decline in interval measure (IM). Similar to profitability, the government's indirect taxation policy had a significant negative effect on the assets, 
sales and income per employee as well as capacity utilisation. Increasing CAPUT levels and exports also had a significantly positive impact on SE. Export sales ratios had no significant bearing on CAPUT levels nor did the central bank interest rate have any significant role in any of the efficiency indicators except IM. For IM, export sales ratios had a positive effect while interest rates had a negative effect. Hence broadly speaking, contrary to profitability ratios, the long term impact of reforms on privatised firms efficiency indicators appear to be a generally not negative. This finding of long term improvement in efficiency is in fact similar to Ghulam and Jaffry (2015) of the Pakistani cement industry productivity.

[Insert table 4 about here]

Financial leverage, liquidity and solvency

A major criticism of the firms operating under state ownership was that most of them were not only less profitable and inefficient but in fact they were technically insolvent with severe liquidity constraints. Hence, one of the major objectives of transferring to private ownership was to make them survive and keep them liquid and solvent in a longer time period without any recourse to public funds. For privatised firms, starting with debt or financial leverage (LEVER) which comprises long and short term borrowing, this decreased immediately after privatisation and this trend continued over medium and longer time periods (see Table 5). The sum of individual coefficients show that decrease was statistically significant over a longer time period (up to 15 years after transfer of ownership). Furthermore, regression results also confirmed that rising export revenues would help reduce leverage for the group of privatised firms.

Interestingly, regression results after controlling for other factors did not support a significant effect of change of ownership on CR in any of the post-privatisation sub-periods. The impact is positive but statistically insignificant. The estimates also confirmed the point that increase in sales tax negatively impacted CR. Surprisingly, an increase in CAPUT would also have a similar impact on firms' liquidity. One reason could be the fact that increases in CAPUT could increase wear and tear of the machinery which would require higher maintenance cost. 
[Insert table 5 about here]

The second measure of liquidity employed is the WCR. The regression results showed WCR, in fact declined significantly over the 6-10 years post-privatisation after controlling industrial and economic conditions. The sum of individual coefficients estimates also show that the long term impact is also negative and statistically significant. An increase in CAPUT would help increase WCR. Surprisingly, an increase in sales tax payment also increased WCR. By using an alternative measure such as NWTL, the improvement was also statistically significant for the privatised group of firms over shorter and medium post-privatisation time periods. Aggregation of individual coefficients confirmed that net worth of the privatised firms relative to their liabilities in fact improved over a longer time period after the transfer of ownership. Similarly to leverage, export revenues increased the net worth of firms.

A second approach to assess solvency is the use of the income statement ratios. We employed time interest earned (TIE) defined as gross profit plus depreciation minus operating expenses and then divided by financial expenses. This ratio measures the number of times resources are available to pay off financial expenses. Interestingly, regression results did not even support improvement over a shorter post-privatisation time period. Furthermore, regression results also confirmed the fact that for privatised firms, an increase in sales tax would reduce the cash cushion for interest expenses.

\section{Output and investment}

The regression estimates relating to individual time specific dummy variables contained in Table 6 reveals that the increase in real sales during the longer time periods was statistically significant for the 16-20 years post privatisation period. The combined impact measured by adding four regression coefficients was not statistically significant. Similarly, the regression results in Table 6 did not show any significant improvement in the capital spending after controlling for firm and industry specific factors and economic environment. This was true of individual post privatised dummy variables as well as combined effect. One of the interesting messages from the regression result was the negative impact of government taxes (excise duty and sales tax) on real sales of the privatised firms. Both taxes we considered in this case were indirect taxes which could have been shifted to consumers. This might 
have resulted in a decrease in demand due to increasing levels of output prices. As anticipated, higher capacity utilisations and firm size increased output measured by real sales. However, an unexpected result in this case was the negative impact of GDP growth on real sales. In the case of investment, with the exception of two variables (one for each investment indicator dependent variable), all other firmsspecific, industry and economic conditions had no statistically significant impact.

\section{[Insert table 6 about here]}

Were the privatised firm's findings different from other comparable firms in the industry?

Despite our efforts in controlling a number of factors in multivariate regression, attributing bad or good performances purely on a change of ownership could be subject to debate for a variety of reasons. We carried out a sensitivity analysis exercise and compared the privatised firm's performance against those ten firms that were set up under private ownerships and remained so subsequently throughout our sample period. We slightly modified our regression model where four dummy variables representing post ownership change were replaced with post reforms time period. The new dummy variables in fact represent post reforms period (1991/92 onward when first firms were privatised). We also dropped initial condition variables because they are not relevant in this case of private firms. Table 7 contains regression estimates of those dependent variables which were either used extensively in the literature on this issue or produced statistically significant coefficients (Tables 3-6) after aggregation of individual post ownership change time specific variables and their coefficients.

We focus on the estimates contained in the last four lines of Table 7. Broadly speaking, the performance of privatised firms appeared to be relatively better based on the financial performance indicators represented by eight dependent variables except profitability (ROS). The estimates related to ROS did confirm that profitability declined for the private firms, but the decline was not statistically significant. Sale efficiency and capacity utilisation improved but the improvement was not statistically significant. The outcome of dependent variables representing financial strengths and health (LEVER, WCR and NWTL) also did not show any better than privatised firms except NWTL which showed a better 
situation for the longer time period (1-15 years after reforms). Real sales and investment declined and the decline is statistically significant too.

\section{Further understanding of long run reversed profitability effect}

The contribution of this study as discussed before is not only limited to long run performance evaluation of an industry in a developing country setting, but to also understand how short run performance evaluation, which has been the main feature of the most of the early studies on the issue, may have overestimated the impact on profitability performance in particular. The generalisation of developed countries findings in terms of positive profitability impacts of reforms and privatization to all the developing countries and industries could also be subject to debate unless, a number of case studies in this context for different economic and political and corporate settings are available. We highlighted the fact in the introduction section of the paper that most post 2004 published/completed studies, in particular covering a longer post reforms period, are related to planned economies such as China and Vietnam, and this could suffer generalisation issues. Our empirical results for the Pakistani cement industry clearly show that contrary to short term positive effects, long term financial implications in terms of profitability of the reforms including privatization could be less assured. This finding is confirmed by our case study using parametric tests. In the following, we discuss factors which could have contributed to at best modest results, and at worst, a decrease in profitability, in particular over a longer run of the Pakistani cement industry.

We first start with the role of macroeconomic conditions that could have serious effects on the long run profitability of an industry after reforms and privatisation. In an effort to further understand the contribution of macroeconomic environments in improving or negatively affecting privatised firms profitability performance, Table 8 shows statistics for two sub-periods: 1986-92 for pre privatisation periods and 1993-2011 for post. The statistics contained in Table 8 clearly show that macroeconomic conditions were less favourable subsequent to the launch of the privatisation policy. A significant and gradual increase in sales tax (indirect tax which is generally passed on to consumers) had pushed retail 
output prices up after reforms and privatisation, and thus negatively affected demand for cement and subsequently eroded margins. Unemployment and interest rates were higher, earning yields were marginally less, growth in public sector investment, government development expenditures, foreign investment, construction sector activity and GDP growth rate, all of these factors that boost demand for cement performed less favourably and perhaps contributed to stagnant or a reduced level of industry earning over the longer time period. The negative impact of these variables had offset any positive effect of reforms and change of ownership over a longer time period. This indeed proves the point that a longer run positive impact of reforms on firms' profitability in particular depends on favourable macroeconomic conditions and government fiscal policy in general and taxation in particular, which were not commonly discussed in the earlier studies using the shorter post reforms period.

\section{[Insert Table 8 here]}

Broadly speaking and as discussed before, a significant number of earlier studies conducted in the 1990s on the impact of privatisation on firms' performance either did not consider the dynamic impact, or under estimated the influence of broader deregulation regimes on input prices in particular over the longer time period. The modest improvement or a decline in profitability could be partially explained by a significant upward adjustment in input prices over the longer time period, due to freedom of setting input prices. The following Table 9 clearly shows that any increase in output prices for the cement industry, was in fact eaten up by a significant increase in fuel and raw material prices during the longer run post reforms and privatisation time period. The fuel prices and related cost constitute a significant portion of the overall cost of cement production and a more than $13 \%$ annual growth in this cost element surely reduced the profit margins. Industry in general was unable to pass on the increase in input prices to customers over the longer time period due to less than anticipated demand, considering the macroeconomic environment discussed above. Some firms moved from furnace oil to coal as an energy source but as shown in the Table 9, the increase in coal price was also higher than output price increase over the longer time period.

[Insert table 9 here] 
Alongside the economic environment and the dynamic effect of a deregulated inputs market, the majority of studies evaluating immediate short run effects do not discuss the implications of long run increase in political risk in a developing country context. The frequent change of governments, deterioration in law \& order due to terrorism in an increasing number of countries, could affect both publically and privately owned firms but the long run impacts on private sector firms could be more severe due to a lack of cushion provided by state ownership. With the exception of the period between 2000 -2006, Pakistan faced turmoil in the governance of the country. The political governments were toppled four times by the presidential orders during the first ten years of post-privatisations and privatisation period. This led to uncertainty in the business sector in particular. This resulted in a decrease in demand for a significant post reforms time period. The majority of privatised firms made a significant investment in capacity additions and technology upgrades immediately after the change of ownership by using borrowed money from the financial markets. The depressed demand due to political environment alongside an increase in central bank discount rates resulted in higher financial expenses per unit produced, which contributed to a decrease in profit margins over the longer time period.

Similarly, one of the other often ignored facts in a developing country context is the intentional under declaration of profitability in some cases to avoid paying corporate taxes or to escape being under the radar by the competition authorities. The discussion on this issue is beyond the scope of this study but news items in the local press on the understatement of income by corporate and personnel sectors are a rather regular appearance. Nonetheless, considering these issues, it is not surprising to see that the positive impact of reforms on profitability in particular has been limited to immediate post reforms period.

Another element often ignored in the short sample studies is the changes in the dynamics of competition over the longer time period. In the context of the Pakistani cement industry, there have been allegations of collusion among cement producers since the reforms were introduced and ownership was transferred to the private sector. Producers associations' office had been raided by the investigation agencies and competition authorities. A study yet to be published by the authors of this study confirmed a decrease 
in competition levels over the longer post reforms period. To maintain the stability in collusion prices, producers had increased the production capacity to maintain market share. The depress demand and uneconomical increase in capacity resulted in a decrease in capacity utilisations as discussed above. The increase in competition levels abroad has also not helped in absorbing the excess capacity in an export market. All this resulted in a pressure on profitability margins over a longer time period. Interestingly, and as discussed above, these potential long run dynamics after transfers of ownership had not been discussed in earlier studies which have become relevant in our case and could be true for a number of other developing countries.

\section{Conclusion}

Our review of the literature on the impact of reforms and privatisation on financial and operational performance of firms and industry revealed inconsistent conclusions. Some studies clearly showed a positive impact while others showed either negative or at best no impact at all. We argue that these contrasting conclusions could have been due to a short sample time period of the studies, methodological issues or geographic location of the sample firms (probably too much focus on firms in developed countries and recently China). By using the Pakistani cement industry as a case study, we evaluated financial performance of firms during pre- and post-privatisation time periods. Compared to a significant number of earlier studies in this area, we assembled and utilised accounting and operational data over a quarter of a century. Our regression based parametric tests accommodated initial conditions as well as firm and industry specific factors.

Based on a number of profitability ratios, multivariate regression results confirmed the findings for privatised firms after controlling factors beyond the management's control and initial conditions that privatised firms became more profitable in the first 5 years, but since then became significantly less profitable over longer post-ownership change periods compared to public ownership levels. Broadly speaking, efficiency results were contrary to profitability. More specifically, regression results confirmed significant sale efficiency and capacity utilisation improvement over a longer time period 
after the transfer of ownership. The net income and assets per employee also improved but the improvement was not statistically significant. Furthermore, the privatised firms adjusted well and adopted a lenient credit sales policy to keep intact their customer base in the face of new competition environment after broader reforms.

Continuing with relatively better efficiency indicators after a change of ownership, regression estimates validated the medium and longer term increase in net-worth of the group of privatised firms over medium and longer term periods. Similarly, as expected, privatised firms also reduced their debt and became less leveraged over the shorter, medium and longer time periods. The cash ratio also improved over a longer time period but regression results did not support a statistically significant improvement for these group of privatised firms. The working capital ratio did improve initially but the regressions results however, supported the fact that working capital ratio declined over the medium and longer post privatisation years. The solvency indicator represented by interest cover showed that, time interest earned of privatised firms reduced over longer run post- privatisation time periods but regression results did not confirm that this decline in interest cover for the group of privatised firms was statistically significant.

Finally, the output approximated by real sales value did not increase significantly for privatised firms over a broader longer run period despite a significant increase after 15 years of change of ownership. Similarly, regression results after controlling for other factors did not show any statistically significant improvement. Regression results in fact confirmed a statistically significant decline over 16-20 years post-privatisation time period. Lastly, we tried to trace the decline in profitability by considering a number of factors that included macroeconomic environment, industry conditions, political risk, competitive conditions and dynamic effects of deregulated inputs market. We argue that despite a significant role of these factors in explaining the long run disappointing profitability outcome in our case study, a number of early influential empirical studies did not focus on these factors adequately and could have overestimated the impact of broader economy wide reforms and privatisation on privatised firm’s profitability over the longer post ownership time period in particular. 
Despite making an effort to perform a comprehensive analysis of the impact of reforms and privatisation on firms' financial and operational performance, our study still has some limitations. It would have been more appropriate if a social cost-benefit analysis of the policy change was also performed. We carried out such an analysis but due to the nature and aims of this study and length of the paper, we do not report and discuss these estimates. We hope to publish these findings in a future study. Another limitation of our study is that this is related to a country which has witnessed significant troubles since 2000 due to political turmoil and terrorism related activities. Hence, long term conclusions could have been influenced by these issues. It would have been more appropriate to compare our case study results to a similar country which had introduced reforms at about the same time such as India to compare and contrast our broader conclusions during this time period. We leave this for future research. It would be desirable with more financial resources to try and collect data on other comparable manufacturing industries and perform similar analyses over a longer time period. Nonetheless, our study despite these limitations will hopefully provide a useful reference for future studies on the long term impact of reforms on an industry’s and individual firms' financial and operational performance.

\section{References}

Adam, C. and P. S. Mistry (1992), ‘Adjusting Privatization: Case Studies from Developing Countries’, James Currey.

Aftab, S. and S.R. Khan (1995), 'Comparative Privatisation Experience in Pakistan: Employee Vs Private Ownership’, Research Report. Pakistan: Sustainable Development Policy Institute (SDPI). Aharoni, Y. (1986), 'The Evaluation and Management of State Owned Enterprises', Cambridge, Mass.: Ballinger.

Atkinson, S.E. and R. Halvorsen (1986), 'The Relative Efficiency of Public and Private Firms in a Regulated Environment: The Case of U.S. Electric Utilities', Journal of Public Economics 29(3), 281294.

Bennett, J. T. and M. H. Johnson (1979), 'Public Versus Private Provision of Collective Goods and Services: Garbage Collection Revisited', Public Choice, 341, 55-63. 
Bishop, M. R. and J. A. Kay (1989), 'Privatisation in the United Kingdom: Lessons from Experience’, World Development, Vol. 17, No. 5, 643-657.

Boardman, A. E. and A. R. Vining (1989), 'Ownership and Performance in Competitive Environments: A Comparison of the Performance of Private, Mixed, and State-Owned Enterprises', Journal of Law and Economics, 1-33.

Boubakri, N. and J. C. Cosset (2002), 'Does Privatisation Meet the Expectations in Developing Countries? A Survey and some Evidence from Africa', Journal of African Economies, 11suppl 1, 111140.

Boubakri, N., Cosset, J. C. and O. Guedhami (2004), 'Privatization, Corporate Governance and Economic Environment: Firm-Level Evidence from Asia’, Pacific-Basin Finance Journal, 121, 65-90. Boubakri, N., Cosset, J. C. and O. Guedhami (2005), 'Postprivatization Corporate Governance: The Role of Ownership Structure and Investor Protection', Journal of Financial Economics, 762, 369-399. Boycko, M., Shleifer, A. and R. W. Vishny (1993), 'A Theory of Privatisation', Working Paper, Harvard University.

Caves, D. W. and L. R. Christensen (1980), 'The Relative Efficiency of Public and Private Firms in a Competitive Environment: The Case of Canadian Railroads', The Journal of Political Economy, 958976.

Chen, G., Firth, M. and O. Rui (2006), 'Have China's Enterprise Reforms Led to Improved Efficiency and Profitability? ', Emerging Markets Review, 71, 82-109.

Cook, P. and Y. Uchida (2008), 'The Performance of Privatised Enterprises in Developing Countries', The Journal of Development Studies, 449, 1342-1353.

D'Souza, J., Megginson, W. and R. Nash (2005), 'Effect of Institutional and Firm-Specific Characteristics on Post-Privatization Performance: Evidence from Developed Countries', Journal of Corporate Finance, 115, 747-766.

Farinos, J. E., Garcia, C. J. and A. M. Ibanez (2007), 'Operating and Stock Market Performance of State-Owned Enterprise Privatizations: The Spanish Experience', International Review of Financial Analysis, 164, 367-389. . 
Foreman-peck, J. and D. Manning (1988), 'How well is BT Performing? An International Comparison of Telecommunications Total Factor Productivity’, Fiscal Studies, 93, 54-67.

Galal, A., Jones, L. P., Tandon, P. and I. Vogalsang (1994), 'Welfare Consequences of Selling Public Enterprises’, The World Bank, Washington D.C.

García, L. C. and S. G. Ansón (2012), 'What Drives the Operating Performance of Privatised Firms? ', Scottish Journal of Political Economy, 591, 1-27.

Ghosh, S. (2008), 'Does Divestment Matter for Firm Performance? Evidence from the Indian Experience', Economic Systems, 324, 372-388.

Ghulam, Y. and S. Jaffry (2015), 'Efficiency and Productivity of the Cement Industry: Pakistani Experience of Deregulation and Privatisation', Omega, 54, 101-115.

Government of Pakistan, Economic Advisor Wing, Ministry of Finance. Economic Survey. Various issues, Islamabad, Pakistan.

Government of Pakistan, Expert Advisory Cell, Ministry of Production. Annual Report of Public Enterprises Various issues, Islamabad, Pakistan.

Government of Pakistan, Federal Bureau of Statistics FBS. Census of Manufacturing Industries CMI Various issues, Karachi, Pakistan.

Government of Pakistan, Federal Bureau of Statistics FBS. 1998. Fifty Years in Pakistan Statistics Islamabad, Pakistan.

Government of Pakistan, National Development Finance Corporation NDFC. 1991. Cement Directory Karachi, Pakistan.

Government of Pakistan, State Bank of Pakistan SBP. Monthly Statistical Bulletin Various issues, Karachi, Pakistan.

Handoussa, H. and G. Potter (1991). 'Employment and Structural Adjustment: Egypt in the 1990s', Cairo: American University in Cairo Press.

Harper, J. T. (200)1, 'Short-Term Effects of Privatization on Operating Performance in the Czech Republic', Journal of Financial Research, 241, 119-31.

Hausman, J. A. and W. E. Taylor (1981), 'Panel Data and Unobservable Individual Effects', Econometrica: Journal of the Econometric Society, 1377-1398. 
Huang, L. and Y. Yao (2010), 'Impacts of Privatization on Employment: Evidence from China', Journal of Chinese Economic and Business Studies, 8(2), 133-156.

Huang, Z. and K. Wang (2011), 'Ultimate Privatization and Change in Firm Performance: Evidence from China', China Economic Review, 221, 121-132.

Li, D., Moshirian, F., Nguyen, P. and L. W. Tan (2007), 'Managerial Ownership and Firm Performance: Evidence from China's Privatizations', Research in International Business and Finance, 213, 396-413. Loh, A. T., Kam, B. H. and J. T. Jackson (2003), 'Sri Lanka's Plantation Sector: A before-and-after Privatization Comparison', Journal of International Development, 15(6), 727-745.

Mathur, I. and W. Banchuenvijit (2007), 'The Effects of Privatization on the Performance of Newly Privatized Firms in Emerging Markets’, Emerging Markets Review, 82, 134-146.

Megginson, W. L., Nash, R. C. and Van M. Rasdenburgh (1994), 'The Financial and Operational Performance of Newly Privatised Firms: An International Empirical Analysis', The Journal of Finance, Vol. 49 (2), 403-452.

Megginson, W. L. (2016), 'Privatization, state capitalism, and state ownership of business in the 21st century’.

Naqvi, N. H. and A. R. Kemal (1991), 'The Privatisation of the Public Enterprises in Pakistan', The Pakistan Development Review, 30:2, 105-144.

Naqvi, N. H. and A. R. Kemal (1997), 'Privatisation Efficiency and Employment in Pakistan’, in How Does Privatisation Work? Essays on Privatisation in honor of Professor V.V. Ramanadham, Routledge, 11 New Fetter Lane London EC4P 4EE.

Naceur, S. B., Ghazouani, S. and M. Omran (2007), 'The Performance of Newly Privatized Firms in Selected MENA Countries: The Role of Ownership Structure, Governance and Liberalization Policies’, International Review of Financial Analysis, 16(4), 332-353.

Petersen, M. A. (2009), 'Estimating Standard Errors in Finance Panel Data Sets: Comparing Approaches', Review of financial studies, 22(1): 435-480.

Shaikh, H. A. (1985), 'Efficiency in Production under Private and Public Ownership: Techniques of Measurement and Evidence from Pakistan', PhD Dissertation Submitted to the Graduate School, Boston University, USA. 
Villalonga, B. (2000), 'Privatization and Efficiency: Differentiating Ownership Effects from Political, Organizational, and Dynamic Effects’, Journal of Economic Behavior and Organization, 421, 43-74.

Wei, Z., Varela, O., D'Souza, J. and M. K. Hassan (2003), 'The Financial and Operating Performance of China's Newly Privatized Firms', Financial Management, 107-126.

Zhang, X., Tang, Z. and J. He (2012), 'Impact of Macro and Firm-Specific Characteristics on Postprivatization Performance’, Chinese economy, 455, 50-91. 
Table 1: Twenty influential studies on the impact of broader reforms and privatization since 1989 (in chronological order of publication year)

\begin{tabular}{|c|c|c|c|}
\hline Authors & Year & Sample / type of firms & Results \\
\hline Bishop and Kay & 1989 & $\begin{array}{l}\text { Shipping, airlines, gas, telecommunication, oil and } \\
\text { automobile industries }\end{array}$ & $\begin{array}{l}\text { Most of the privatized industries have grown since privatization and grown more than those industries that have remained in the } \\
\text { public sector. While output and profit have grown, margins have increased, employment has declined. }\end{array}$ \\
\hline Adam and Mistry & 1992 & Industrial enterprises of $8 \mathrm{DCs}$ & Privatization improved profitability and efficiency. \\
\hline Megginson et al. & 1994 & $\begin{array}{l}\text { Panel of forty-one enterprises from fifteen } \\
\text { countries }\end{array}$ & $\begin{array}{l}\text { Strong performance improvements without lowering employment. Firms increased real sales, become more profitable, increased } \\
\text { capital investment spending and improved their operating efficiency. }\end{array}$ \\
\hline Villalonga & 2000 & Longitudinal study of 24 Spanish firms & Negative effect of reforms is eventually offset by the positive effects of the change of ownership. \\
\hline Harper & 2001 & 178 privatized Czech firms & Profitability and efficiency decreased immediately after privatization. Decrease in employment also noted. \\
\hline Boubakri and Cosset & 2002 & 16 African privatized companies & $\begin{array}{l}\text { Profitability improved but not significantly. Efficiency and output decreased slightly but not significantly. Capital expenditures } \\
\text { rose significantly in the post-privatization period. }\end{array}$ \\
\hline Loh et al. & 2003 & Sri Lankan plantation industry & Improvement in performance after privatization \\
\hline Wei et al. & 2003 & 208 Chinese privatized firms & $\begin{array}{l}\text { Significant improvement in real output, real assets, and sales efficiency. No significant change in profitability. However, privatized } \\
\text { firms improved profitability compared to state owned firms during this period. }\end{array}$ \\
\hline Boubakria et al. & 2004 & 50 firms from 10 Asian countries & $\begin{array}{l}\text { Privatization leads to an increase in profitability, efficiency, and output. However, changes less significant than those reported in } \\
\text { other developing countries (DCs). }\end{array}$ \\
\hline D'Souzaa et al. & 2005 & $\begin{array}{l}23 \text { developed countries } \\
129 \text { share-issue }\end{array}$ & $\begin{array}{l}\text { Profitability, efficiency, output, and capital expenditure significantly increased. Ownership, degree of economic freedom, and } \\
\text { level of capital market development significantly affect post privatization performance. }\end{array}$ \\
\hline Boubakri et al. & 2005 & 230 companies from DCs' & $\begin{array}{l}\text { Significant increase in profitability, efficiency, investment and output. Changes in performance dependent on macro-economic } \\
\text { reforms and environment, and the effectiveness of corporate governance. Economic growth is associated with higher profitability } \\
\text { and efficiency gains; trade liberalization is associated with higher levels of investment and output, while financial liberalization is } \\
\text { associated with higher output changes. Higher improvements in efficiency for firms in countries in which stock markets are more } \\
\text { developed. }\end{array}$ \\
\hline Chen et al. & 2006 & 1078 Chinese companies of IPO privatization & Decline in profitability and asset utilization. \\
\hline Mathur and Banchuenvijit & 2007 & $\begin{array}{l}103 \text { firms privatized by public share offerings during } \\
1993-2003\end{array}$ & $\begin{array}{l}\text { Increases in profitability, operating efficiency, capital spending, output, and dividend payments as well as decreases in leverage } \\
\text { and total employment. This is true for a wide variety of countries, industries, and competitive environments }\end{array}$ \\
\hline Farinós et al. & 2007 & $\begin{array}{l}\text { Spanish SOEs privatized by public share issue } \\
\text { offerings } 19902001\end{array}$ & $\begin{array}{l}\text { Significant operating improvements in Spanish state owned firms after the privatization. Specifically, they show significant } \\
\text { increases in income efficiency, real sales and employment. }\end{array}$ \\
\hline Naceur et al. & 2007 & $\begin{array}{l}95 \text { privatized firms (Egypt, Morocco, Tunisia, and } \\
\text { Turkey) }\end{array}$ & $\begin{array}{l}\text { Significant increases in profitability and operating efficiency, and significant declines in employment and leverage. Strong } \\
\text { performance improvements for firms that did remain state-owned, were not sold to foreigners, and that came from Egypt. Job } \\
\text { losses are higher in Egypt and in firms where the state is no longer in control. }\end{array}$ \\
\hline Li et al. & 2007 & 155 Chinese firms & Profitability declined. \\
\hline Cook and Uchida & 2008 & 166 companies from developing countries & Deterioration in performance among privatized utilities. \\
\hline Ghosh & 2008 & 99 Indian firms & $\begin{array}{l}\text { Fully government-owned firms significantly less profitable than partially privatized ones. Improvements in profitability largely } \\
\text { occur during the one to three years just before privatization. Leverage and employment effects are spread out over a much } \\
\text { longer period. }\end{array}$ \\
\hline Huanga and Yao & 2010 & $\begin{array}{l}386 \text { Chinese firms privatized in } \\
1995-2001\end{array}$ & $\begin{array}{l}\text { Employment drops more slowly in privatized firms than in pure state-owned firms by a margin of } 17.7 \% \text {. Employment growth } \\
\text { performance of privatized firms improves over time. }\end{array}$ \\
\hline Huang and Wang & 2011 & 124 Chinese firms & Performance improved. More gains in profitability/efficiency when dominant shareholder is an "outsider" \\
\hline Zhang et al. & 2012 & 364 Chinese firms & $\begin{array}{l}\text { Profitability decreased. Output and operating efficiency increased. Economic growth, capital market development, institutional } \\
\text { investors, centralized management, equity refinancing, and external audits are positively associated with post privatization } \\
\text { performance. Market competition, control of large shareholders, central government control, ownership structure balance, and } \\
\text { related-party transact firms' have an impact on performance. }\end{array}$ \\
\hline
\end{tabular}


Table 2: Privatization of publically owned cement manufacturing firms

\begin{tabular}{lccc}
\hline Firm name & $\begin{array}{c}\text { Sale price } \\
\text { (Rs. Mil) }\end{array}$ & $\begin{array}{c}\text { Date of } \\
\text { transfer }\end{array}$ & Buyer name \\
\hline Maple Leaf Cement & 486 & $1 / 1 / 92$ & Nishat Mills Ltd. \\
Mian Jehingir Ellahi \& Ass & Mian Jehingir Ellahi \& Associates \\
Pak Cement & 189 & $1 / 1 / 92$ & Tariq Sehgal \& Associates \\
White Cement & 138 & $1 / 1 / 92$ & EMG \\
D.G Khan Cement & 1961 & $1 / 5 / 92$ & Haji Saifullah \& Group \\
Dandot Cement & 645 & $1 / 5 / 92$ & Sardar M. Ashraf D. Baluch \\
Garibwal Cement & 836 & $1 / 9 / 92$ & Palace Enterprises \\
Zeal Pak Cement & 240 & $1 / 10 / 92$ & EMG \\
Kohat Cement & 569 & $1 / 10 / 92$ & $1 / 1 / 95$ \\
Dandot Works - National Cement & 110 & $1 / 2 / 96$ & Shah Rukh Engineering \\
General Refractories & 19 & $1 / 2 / 96$ & EMG \\
Associated Cement Wah & 2416 & $1 / 11 / 03$ & National Transport Khi \\
Associated Cement Rohri & 255 & $1 / 1 / 04$ & Al Abbass Group \\
Thatta Cement & 794 & $1 / 11 / 05$ & Bestway Cement Limited \\
Mustehkam Cement & 3205 & $1 / 8 / 06$ & Haji Ghani Usman \& Group \\
Javedan Cement Company & 4316 & & \\
\hline
\end{tabular}

Source: Privatization Commission (PC), Government of Pakistan. 
Table 3: Long term determinants of privatized firms' profitability (panel data Hausman Taylor estimator estimates)

\begin{tabular}{|c|c|c|c|c|c|c|}
\hline & ROS & $\mathrm{ROA}_{1}$ & $\mathrm{ROA}_{2}$ & $\mathrm{OPM}_{1}$ & $\mathrm{OPM}_{2}$ & GPM \\
\hline 1-5 years after privatised (a) & -2.5545 & 2.8973 & $5.5921^{* * *}$ & 3.4656 & $4.4154^{* *}$ & $5.6994 *$ \\
\hline 6-10 years after privatised (b) & -1.4800 & -0.6287 & 1.2606 & 1.3128 & 1.6288 & 7.1002 \\
\hline 11-15 years after privatised (c) & -9.0825 & -1.1483 & 0.9828 & -1.8873 & 1.9995 & 1.2548 \\
\hline $16-20$ years after privatised (d) & $-33.5212^{* * *}$ & -7.3556 & -5.1584 & $-34.1883^{* * *}$ & -3.5176 & $-25.6333^{* * *}$ \\
\hline Firm sales tax paid/total revenues & $-60.2775^{* *}$ & $-49.3448^{* * *}$ & $-58.7282^{* * *}$ & $-97.3078^{* * *}$ & $-55.9486^{* * *}$ & $-80.3601^{* * *}$ \\
\hline Firm excise duty paid/total revenues & $-60.6195^{* * *}$ & $-33.2174^{* * *}$ & $-41.3856^{* * *}$ & $-84.4995^{* * *}$ & $-37.2883^{* * *}$ & $-63.4279 * * *$ \\
\hline Firm capacity utilisation & $16.7162^{* * *}$ & $3.2592^{* *}$ & 1.7723 & $14.8675^{* * *}$ & 1.7960 & $10.9174^{* * *}$ \\
\hline Firm export revenues/sales & 0.5564 & $0.7832^{* * *}$ & $0.8088^{* * *}$ & 0.6796 & $0.6484^{* *}$ & 0.8042 \\
\hline Firm size measured by production capacity & $11.1375^{* * *}$ & $-2.9167^{* *}$ & -1.0565 & $18.1803^{* * *}$ & -1.3028 & $17.5251^{* * *}$ \\
\hline Firm assets turn over & $5.6057^{* *}$ & $11.1795^{* * *}$ & $12.7397^{* * *}$ & $7.4965^{* * *}$ & $11.0345^{* * *}$ & 2.5120 \\
\hline Firm working capital ratio & $0.0507^{* * *}$ & $0.0253^{* * *}$ & $0.0160^{* *}$ & $0.0642^{* * *}$ & $0.0192^{* *}$ & $0.0361^{* *}$ \\
\hline Firm age (years) & -2.1242 & -1.7161 & -3.7333 & $-14.7818^{* *}$ & $-4.8639 *$ & $-24.0452^{* * *}$ \\
\hline Firm operating region north $=1,0$ otherwise & 6.5912 & 4.9495 & 4.6917 & 14.6407 & 3.1978 & 13.5973 \\
\hline Firm production process dry $=1,0$ otherwise & 5.9508 & 3.2182 & -1.1599 & -9.2747 & -0.5641 & -13.7670 \\
\hline GDP growth rates & -0.3537 & -0.2757 & $-0.6825^{* *}$ & -1.0202 & $-0.5706^{* *}$ & -0.8155 \\
\hline Central bank base interest rate & $-0.9448^{* *}$ & $-0.5488^{* * *}$ & $-0.4527^{* * *}$ & $-0.9338^{* *}$ & $-0.5023^{* * *}$ & $-0.7254^{* *}$ \\
\hline Industry competition: Herfindhal index & $-214.6688^{*}$ & 75.3303 & 56.5720 & $-268.5185^{*}$ & 38.0642 & -138.3087 \\
\hline Industry profitability & 0.3152 & $0.5983^{* * *}$ & $0.4959^{* * *}$ & $0.7659^{* *}$ & $0.5346^{* * *}$ & $0.7291^{* * *}$ \\
\hline Initial condition: Log of firm assets -5 year before privatisation & 0.4175 & $8.1670^{* * *}$ & $6.3885^{* * *}$ & 3.8147 & $7.9584^{* * *}$ & 0.6145 \\
\hline Initial condition: Leverage -5 year average before privatisation & 0.0011 & -0.0306 & $0.1107^{* *}$ & 0.1184 & 0.0589 & $0.1562^{*}$ \\
\hline Initial condition: perform. -5 year average before privatisation & 0.2367 & $0.6410^{* * *}$ & $0.6242^{* * *}$ & $0.3101^{*}$ & $0.6379^{* * *}$ & $0.2921^{* *}$ \\
\hline Constant & $-103.6261^{* * *}$ & $-51.5917^{* * *}$ & $-33.4591^{* *}$ & $-107.9288^{* * *}$ & $-35.9080^{* *}$ & -40.1367 \\
\hline Observations & 242 & 242 & 242 & 242 & 242 & 242 \\
\hline Number of firms & 11 & 11 & 11 & 11 & 11 & 11 \\
\hline \multicolumn{7}{|l|}{ Empirical tests of parameters (sum of above parameters) } \\
\hline 1-5 years after privatised (a) & -2.5545 & 2.8973 & $5.5921^{* * *}$ & 3.4656 & $4.4154^{* *}$ & 5.6994* \\
\hline $1-10$ years after privatised $(a+b)$ & -4.0345 & 2.2686 & $6.8527^{*}$ & 4.7784 & 6.0442 & $12.7995^{*}$ \\
\hline $1-15$ years after privatised $(a+b+c)$ & -13.1170 & 1.1202 & 7.8355 & 2.8911 & 8.0437 & 14.0544 \\
\hline 1-20 years after privatised $(a+b+c+d)$ & $-46.6381^{* *}$ & -6.2354 & 2.6771 & -31.2973 & 4.5261 & -11.5790 \\
\hline
\end{tabular}

$=$ net after tax income/gross sale, return on assets $\left(\right.$ ROA $\left._{1}\right)=$ net profit before tax/assets, return on assets $\left(\mathrm{ROA}_{2}\right)=$ gross profit (loss)/assets, operating profit margin $\left(\mathrm{OPM}_{1}\right)=($ gross profit (loss)-admin \& selling exp.)/net sale, operating profit margin $\left(\mathrm{OPM}_{2}\right)=$ (gross profit (loss)-admin \& selling exp.)/total assets, gross profit margin (GPM) $=$ (gross profit (loss) + depreciation) $/$ net sale. 
Table 4: Long term determinants of privatized firms' efficiency (panel data Hausman Taylor estimator estimates)

\begin{tabular}{|c|c|c|c|c|c|c|}
\hline & NIE & SE & ASPE & CAPUT & $\mathrm{IM}$ & $\mathrm{ACP}$ \\
\hline 1-5 years after privatised (a) & -0.0414 & $0.7187^{* *}$ & 0.9221 & $8.0565^{* * *}$ & 9.8907 & $19.8212^{* *}$ \\
\hline $6-10$ years after privatised (b) & 0.2271 & $1.1085^{* *}$ & 1.3682 & 1.1741 & -12.1312 & 13.8606 \\
\hline $11-15$ years after privatised (c) & $0.3744^{* *}$ & $1.2502^{* *}$ & 3.0351 & $7.9088^{* *}$ & $-53.1141^{* *}$ & $35.5875^{* *}$ \\
\hline $16-20$ years after privatised (d) & $-0.4643^{* *}$ & 0.7994 & 3.7459 & $18.7642^{* * *}$ & -0.5422 & $96.3032^{* * *}$ \\
\hline Firm sales tax paid/total revenues & $-1.6709^{* *}$ & $-8.9374^{* * *}$ & $-21.8849^{* *}$ & -2.5086 & -113.5342 & 74.9586 \\
\hline Firm excise duty paid/total revenues & $-1.5994^{* * *}$ & $-8.1779^{* * *}$ & $-14.2383^{* *}$ & 12.4574 & -55.8022 & 53.2982 \\
\hline Firm capacity utilisation & $0.1628^{*}$ & $1.2924^{* * *}$ & $2.2931^{* *}$ & $46.1743^{* * *}$ & -16.7105 & $-46.5422^{* * *}$ \\
\hline Firm export revenues/sales & 0.0128 & $0.1447^{* * *}$ & 0.2473 & -0.0925 & $4.8555^{* *}$ & 1.5280 \\
\hline Firm size measured by production capacity & $0.2385^{* * *}$ & $2.9195^{* * *}$ & $5.7886^{* * *}$ & $-5.0170^{* * *}$ & $-20.3543^{*}$ & $-31.5315^{* * *}$ \\
\hline Firm assets turn over & $0.1345^{* *}$ & 0.1452 & $-3.4054^{* * *}$ & $2.5220^{* *}$ & $27.8090^{* * *}$ & 0.2675 \\
\hline Firm working capital ratio & $0.0024^{* * *}$ & $0.0026^{*}$ & 0.0079 & $0.0141^{*}$ & $0.1603^{* *}$ & 0.0051 \\
\hline Firm age (years) & -0.0256 & -0.2645 & 1.4342 & $-8.7108^{* * *}$ & 11.4054 & $-33.3296^{* * *}$ \\
\hline Firm operating region north $=1,0$ otherwise & 0.1759 & 2.6868 & 4.6069 & -3.9439 & 62.5143 & -58.9943 \\
\hline Firm production process dry $=1,0$ otherwise & 0.0162 & -1.9781 & -1.3387 & -3.0558 & -15.8627 & -14.0436 \\
\hline GDP growth rates & $0.0293^{*}$ & $-0.0958^{*}$ & 0.0866 & -0.1796 & 2.3468 & -0.0042 \\
\hline Central bank base interest rate & -0.0129 & -0.0118 & 0.0443 & 0.0668 & $-3.1214^{* *}$ & -0.8119 \\
\hline Industry competition: Herfindhal index & $-7.8405^{* *}$ & -8.7974 & 24.4089 & -11.4659 & $-871.4803^{* *}$ & -165.5714 \\
\hline Industry profitability & $0.0247^{* * *}$ & -0.0127 & -0.1063 & $0.3062^{* * *}$ & 0.6406 & 0.0745 \\
\hline Initial condition: firm assets -5 year before privatisation & -0.0333 & 0.1559 & -0.8071 & $3.6195^{* *}$ & $40.8961^{* * *}$ & 7.7655 \\
\hline Initial condition: firm leverage -5 year average before privatisation & 0.0034 & 0.0067 & -0.0055 & -0.0020 & $-1.5747^{* * *}$ & 0.1146 \\
\hline Initial condition: firm perform. -5 year average before privatisation & -0.0039 & -0.0153 & -0.0459 & $0.1295^{*}$ & $1.0129 *$ & $0.7674^{* *}$ \\
\hline Constant & $-1.2414^{*}$ & $-20.5313^{* * *}$ & $-38.4512^{* * *}$ & $-90.5574^{* * *}$ & 25.4737 & $487.7365^{* * *}$ \\
\hline Observations & 242 & 242 & 242 & 242 & 242 & 242 \\
\hline Number of firms & 11 & 11 & 11 & 11 & 11 & 11 \\
\hline \multicolumn{7}{|l|}{ Empirical tests of parameters (sum of above parameters) } \\
\hline 1-5 years after privatised (a) & -0.0414 & $0.7187^{* *}$ & 0.9221 & $8.0565^{* * *}$ & 9.8907 & $19.8212^{* *}$ \\
\hline $1-10$ years after privatised $(a+b)$ & 0.1856 & $1.8272^{* * *}$ & 2.2903 & $9.2306^{* *}$ & -2.2405 & $33.6819 *$ \\
\hline $1-15$ years after privatised $(a+b+c)$ & 0.5600 & $3.0774^{* * *}$ & 5.3254 & $17.1394^{* * *}$ & -55.3546 & $69.2694 * *$ \\
\hline 1-20 years after privatised $(a+b+c+d)$ & 0.0958 & $3.8768^{* *}$ & 9.0714 & $35.9035^{* * *}$ & -55.8968 & $165.5726 * * *$ \\
\hline
\end{tabular}

Notes: Statistical significance determined by *** $p<0.01,{ }^{* *} p<0.05,{ }^{*} p<0.1$. Capacity utilization and export revenues/total sales treated as endogenous. Dependent variables financial ratios are calculated as explained as follows: net income efficiency $(\mathrm{NIE})=$ net after tax income/labour, sales efficiency $(\mathrm{SE})=$ net sale/labour, assets efficiency $(\mathrm{ae})=$ assets/labour, capacity utilization (CAPUT) = actual production/production capacity, interval measure (IM) = (cash and bank balance + short term investment)/financial expenses, average collection period (ACP) = trade receivables/(net sale/360). 
Table 5: Long term determinants of privatized firms' financial strength (panel data Hausman Taylor estimator estimates)

1-5 years after privatised (a)

6-10 years after privatised (b)

16-15 years after privatised (c)

Firm sales tax paid/total revenues

Firm excise duty pid/total renues

Firm excise duty paid/total revenues

Firm capacity utilisation

Firm size measured by production capacity

Firm size measured

Firm working capital ratio

Firm age (years)

$-7.8145^{* *}$

$-16.2405^{* * *}$

$-1.8368$

$-1.8199$

30.4623

30.4623

$-5.4954^{*}$

$-0.6684$

3.4766
$-14.4678^{* * *}$

$-14.4678^{* * *}$
$-0.0372^{* *}$

$-0.0372$

Firm operating region north $=1,0$ otherwise

Firm production process dry $=1,0$ otherwise

GDP growth rates

Central bank base interest rate

Industry competition: Herfindhal index

Industry profitability

nitial condition: firm assets -5 year before privatisation

Initial condition: firm leverage - -5 year average before privatisation

Initial condition: firm perform. -5 year average before privatisation

Constant

Observations

Number of firms

$-5.9748$

$-14.4081$

0.0004

$-0.0358$

$-107.3592$

$-0.2112$

$-8.9131^{* * *}$
$0.7715^{* * *}$

0.0027

$112.1528^{* * *}$

242

4.0676

1.3716

-3.8311
9.2968

9.2968
$-86.1235^{* *}$

10.9090

10.9090

-1.1071
-0.5532

0.6378

$-10.5872^{* * *}$

$0.8205^{* * *}$

13.6132

11.8151

16.1260

$-1.0590$

$-1.6960^{* * *}$

85.465

0.2226

2.4321

-0.0331
0.1938
5.2197

5.2197

242
11

$-2.5300$

$-54.5275^{* *}$
-33.7392

-33.7392
-47.0683

$211.3684^{* *}$

$211.3684^{* *}$
35.6218

21.8968*

$-0.9058$

$-9.6200$

$-14.7360^{*}$

35.7770

4.3424

53.9838
$4.9288^{* *}$

$4.9288^{* *}$

$.4419 * * *$
-29.7192

$-29.7192$

0.3978

$-19.2441$

-0.5700
0.1283

$-89.5906$

242
11

TIE

NWTL

Empirical tests of parameters (sum of above parameters)

1-5 years after privatised (a)

1-10 years after privatised $(a+b)$

$-7.8145^{* *}$

$-24.0550^{* * *}$

$-25.8918 *$

$\begin{array}{lr}4.0676 & -2.5300 \\ 5.4392 & -57.0575^{*} \\ 1.6081 & -90.7968^{*}\end{array}$

5.4392

10.9048

$-57.0575^{*}$

137.8651*

8.8623

$-1.8951$

-12.6350
29.2785

$-252.0263^{* * *}$

$-93.9956$

-93.9956
-17.0042

$-17.0042$

$-5.6373^{* * *}$
$-51.0389^{* * *}$

$-51.0389^{* * *}$
$58.7667^{* * *}$
0.0171

58.7667
0.0171

$-3.5186$

30.1538
-15.3729

$-15.3729$

1.6029

$-1.9492$

-143.9767
0.0289

0.0289
$60.5263^{* * *}$

$60.5263^{* *}$
-0.4065

$-0.4065$

$2.8611^{* * *}$

242

2.6628

$24.7628^{* * *}$

11.5257
-6.0658

-6.0658
$71.5023^{* *}$

1.5078

$16.0458^{* * *}$

$1.8206^{* * *}$

$9.1117^{* * *}$

$-12.0580^{* * *}$

$-12.0580^{* * *}$
$0.1050^{* * *}$

$-26.9962 * * *$

1.0388

1.0388

-22.6919
$2.0533^{* * *}$

0.4044

0.4044

$430.6402^{*}$
$0.4929^{*}$

$7.4941^{* *}$

0.0716

0.0716

-0.0941
$-87.3244^{* *}$

242

Nos: Starticas

$p<0.01, * * p<0.05,{ }^{*} p<0.1$. Capacity utilization and export revenues/total sales treated as

explained as follows: leverage ratio (assets-current liabilities)/total liabilities, time interest earned (TIE) = (gross profit- admin + selling exp. \& depreciation)/financial expenses. 
Table 6: Long term determinants of privatized firms' output and investment (panel data Hausman Taylor estimator estimates)

\begin{tabular}{|c|c|c|c|}
\hline & RSALE & CES & CEA \\
\hline 1-5 years after privatised (a) & 1.8391 & -5.8205 & 3.7147 \\
\hline 6-10 years after privatised (b) & -1.0777 & -14.0642 & -0.1521 \\
\hline 11-15 years after privatised (c) & 4.7823 & -32.3398 & -10.3561 \\
\hline $16-20$ years after privatised $(\mathrm{d})$ & $19.4596^{* *}$ & $-80.1821^{*}$ & -13.2366 \\
\hline Firm sales tax paid/total revenues & $-96.3256^{* * *}$ & 183.2738 & 24.7543 \\
\hline Firm excise duty paid/total revenues & $-33.6381^{*}$ & 53.4203 & 7.1234 \\
\hline Firm capacity utilisation & $26.0086^{* * *}$ & -21.5844 & $6.7408^{*}$ \\
\hline Firm export revenues/sales & 0.3476 & 1.6696 & $1.0332^{*}$ \\
\hline Firm size measured by production capacity & $29.9427^{* * *}$ & -19.8800 & -2.3995 \\
\hline Firm assets turn over & 2.0640 & $-52.5491^{* * *}$ & $-10.0711^{* * *}$ \\
\hline Firm working capital ratio & 0.0057 & 0.0955 & 0.0186 \\
\hline Firm age (years) & -0.2562 & 46.9261 & $13.0918^{* *}$ \\
\hline Firm operating region north $=1,0$ otherwise & 19.5350 & 12.6807 & -0.5145 \\
\hline Firm production process dry $=1,0$ otherwise & -13.3108 & 9.6619 & 3.2436 \\
\hline GDP growth rates & $-1.2657^{* *}$ & 1.0205 & 0.5880 \\
\hline Central bank base interest rate & 0.3108 & 0.3925 & -0.5821 \\
\hline Industry competition: Herfindhal index & -39.8785 & $1,702.1786^{* *}$ & 104.2079 \\
\hline Industry profitability & -0.0100 & 0.1584 & 0.0937 \\
\hline Initial condition: firm assets -5 year before privatisation & -2.6632 & 15.3990 & -0.6385 \\
\hline Initial condition: firm leverage -5 year average before privatisation & -0.0084 & -0.5601 & -0.0509 \\
\hline Initial condition: firm perform. -5 year average before privatisation & -0.2110 & 0.0161 & -0.1002 \\
\hline Constant & $-248.3336^{* * *}$ & -115.7399 & -44.3735 \\
\hline Observations & 242 & 231 & 231 \\
\hline Number of firm & 11 & 11 & 11 \\
\hline \multicolumn{4}{|l|}{ Empirical tests of parameters (sum of above parameters) } \\
\hline 1-5 years after privatised (a) & 1.8391 & -5.8205 & 3.7147 \\
\hline 1-10 years after privatised $(a+b)$ & 0.7614 & -19.8847 & 3.5625 \\
\hline 1-15 years after privatised $(a+b+c)$ & 5.5437 & -52.2244 & -6.7936 \\
\hline 1-20 years after privatised $(a+b+c+d)$ & 25.0032 & -132.4065 & -20.0301 \\
\hline
\end{tabular}

Notes: Statistical significance determined by ${ }^{* * *} \mathrm{p}<0.01,{ }^{* *} \mathrm{p}<0.05,{ }^{*} \mathrm{p}<0.1$. Capacity utilization and export revenues/total sales treated as endogenous. Dependent variables financial ratios are calculated as real sales (RSALE) $=$ gross sales/price index (cement), capital expenditure to sale $(C E S)=[$ fixed assets fixed assetst-1 ]/ net sales, capital expenditure to assets (CEA) $=[$ fixed assets - fixed assetst-1 $] /$ total assets. 
Table 7 Sensitivity analysis: comparison with always privately owned firms

\begin{tabular}{|c|c|c|c|c|c|c|c|c|}
\hline & ROS & SE & CAPUT & LEVER & WCR & NWTL & RSALE & CES \\
\hline $1-5$ years after reforms (a) & -2.5304 & -0.7463 & 2.3900 & -5.4464 & $47.6050 *$ & 5.2920 & $-26.3411 * *$ & $-105.6212 * * *$ \\
\hline $6-10$ years after reforms (b) & -0.6139 & 1.0280 & 0.3027 & -10.2088 & 23.3232 & 13.7948 & $-30.6568 * *$ & $-77.3050 *$ \\
\hline $11-15$ years after reforms (c) & -4.5832 & 1.3448 & 5.3089 & -11.7899 & 21.7950 & 19.6739 & -18.4188 & -72.3993 \\
\hline $16-20$ years after reforms (d) & -4.2306 & 0.5291 & $13.4842^{* *}$ & -12.3729 & 5.4829 & 12.5569 & -26.2835 & -37.9585 \\
\hline Firm sales tax paid/total revenues & 2.4509 & 1.1496 & $\begin{array}{l}10.4042 \\
-2.8716\end{array}$ & -13.0722 & 28.6330 & 17.5081 & $-50.0807^{*}$ & $202.2461^{* *}$ \\
\hline Firm excise duty paid/total revenues & 7.1438 & 0.8209 & -4.6741 & $-32.2760 * * *$ & -21.0301 & 1.8123 & -14.2948 & -9.9366 \\
\hline Firm capacity utilisation & $14.8725^{* * *}$ & $1.7484^{* * *}$ & $66.6543^{* * *}$ & 2.7797 & 2.4479 & 1.6268 & $39.4632 * * *$ & $-29.8554 *$ \\
\hline Firm export revenues/sales & -0.7940 & -0.0065 & -0.4335 & 0.8699 & 6.3008 & 0.3945 & $-3.2161 *$ & -4.9883 \\
\hline Firm size measured by production capacity & 0.3297 & $2.0506^{* * *}$ & $-3.0429 * *$ & -1.0435 & $-18.9088^{*}$ & -3.8067 & $45.8051^{* * *}$ & $-41.5090 * * *$ \\
\hline Firm age (years) & 9.1253 & 0.5611 & $-6.5161 * *$ & -3.3345 & 22.1850 & -8.9152 & $25.7596 * *$ & $105.4321^{* *}$ \\
\hline Firm assets turn over & -1.2539 & $-0.5663 * * *$ & $-2.8465 * * *$ & $-5.8684 * *$ & $28.1191^{* * *}$ & $-17.0822^{* * *}$ & -0.4777 & $-41.5897^{* * *}$ \\
\hline Firm working capital ratio & $0.0415 * *$ & -0.0035 & 0.0079 & -0.0343 & & $0.1171^{* * *}$ & -0.0141 & -0.1468 \\
\hline Firm operating region north $=1,0$ otherwise & 4.2942 & -0.1703 & -3.0770 & 0.0154 & 9.6630 & -2.7804 & 3.0755 & 41.3688 \\
\hline Industry competition: Herfindhal index & 143.7047 & $41.8485^{* *}$ & -116.2144 & -93.6412 & -617.7114 & 179.9805 & 229.8354 & -650.5298 \\
\hline Industry profitability & $0.8594^{* * *}$ & $0.1223^{* * * *}$ & $0.3733^{* *}$ & -0.5587 & -1.7378 & 0.0172 & 0.5432 & 2.5267 \\
\hline GDP growth rates & 0.4889 & -0.0900 & $-0.4773 *$ & -0.1902 & 2.3754 & -0.2635 & -1.0556 & 2.7325 \\
\hline Central bank base interest rate & -0.2455 & $0.1095 *$ & $0.7228^{* *}$ & -0.8861 & -1.7247 & -0.1065 & $1.8698^{*}$ & $6.3177^{* *}$ \\
\hline Constant & $-99.4204 * * *$ & $-24.1545^{* * *}$ & $-164.2859 * * *$ & $70.3910^{*}$ & 34.5193 & $103.0568^{* *}$ & $-507.1691^{* * *}$ & 186.4745 \\
\hline Observations & 165 & 165 & 165 & 164 & 165 & 165 & 165 & 155 \\
\hline Number of firms & 10 & 10 & 10 & 10 & 10 & 10 & 10 & 10 \\
\hline \multicolumn{9}{|c|}{ Empirical tests of parameters (sum of above parameters) } \\
\hline $1-5$ years after reforms (a) & -2.5304 & -0.7463 & 2.3900 & -5.4464 & $47.6050 *$ & 5.2920 & $-26.3411 * *$ & $-105.6212^{* * *}$ \\
\hline $1-10$ years after reforms $(a+b)$ & -3.1442 & 0.2817 & 2.6927 & -15.6552 & 70.9282 & 19.0868 & $-56.9978 * * *$ & $-182.9263^{* *}$ \\
\hline $1-15$ years after reforms $(a+b+c)$ & -7.7274 & 1.6265 & 8.0016 & -27.4451 & 92.7232 & $38.7608^{*}$ & $-75.4167 * *$ & $-255.3255^{* *}$ \\
\hline $1-20$ years after reforms $(a+b+c+d)$ & -11.9580 & 2.1556 & 21.4857 & -39.8180 & 98.2061 & 51.3177 & $-101.7002 * *$ & $-293.2841 *$ \\
\hline
\end{tabular}


Table 8: Contribution of macroeconomic environment

\begin{tabular}{|c|c|c|c|c|c|c|c|c|c|}
\hline & $\begin{array}{l}\text { Unemp. } \\
\text { rate }\end{array}$ & $\begin{array}{l}\text { Interest } \\
\text { rate }\end{array}$ & $\begin{array}{c}\text { Earning } \\
\text { yields }\end{array}$ & $\begin{array}{l}\text { Pubic } \\
\text { invest } \\
\text { growth } \\
\text { rate }\end{array}$ & $\begin{array}{l}\text { Develop. } \\
\text { exp. } \\
\text { Growth } \\
\text { rate }\end{array}$ & $\begin{array}{l}\text { Foreign } \\
\text { investment } \\
\text { growth } \\
\text { rate }\end{array}$ & $\begin{array}{l}\text { Const. } \\
\text { growth } \\
\text { rate }\end{array}$ & $\begin{array}{l}\text { GDP } \\
\text { growth } \\
\text { rate }\end{array}$ & $\begin{array}{c}\text { Sales tax } \\
\text { as a } \% \text { of } \\
\text { gross } \\
\text { sale }\end{array}$ \\
\hline $1986-92$ & 4.03 & 10.00 & 11.69 & 14.59 & 16.00 & 30.39 & 5.88 & 5.90 & 3.00 \\
\hline $1993-2011$ & 6.32 & 12.47 & 10.96 & 10.89 & 11.00 & 22.11 & 2.91 & 4.27 & 8.00 \\
\hline
\end{tabular}

Notes: figures in \%.

Table 9: Long run dynamic impact of broader economy-wide reforms on input prices

\begin{tabular}{lccccc}
\hline & $\begin{array}{c}\text { Cement output } \\
\text { price growth } \\
\text { rate }\end{array}$ & $\begin{array}{c}\text { Furnace oil price } \\
\text { growth rate }\end{array}$ & $\begin{array}{c}\text { Coal price } \\
\text { growth } \\
\text { rate }\end{array}$ & $\begin{array}{c}\text { Fuel price } \\
\text { growth } \\
\text { rate }\end{array}$ & \multicolumn{2}{c}{$\begin{array}{c}\text { Raw material } \\
\text { prices growth } \\
\text { rate }\end{array}$} \\
\hline $1986-92$ & 8.48 & 6.45 & 4.68 & 7.93 & 10.56 \\
$1993-2011$ & 7.70 & 18.90 & 8.59 & 13.20 & 12.93 \\
\hline Notes: figures in \%. & & & & &
\end{tabular}

